\title{
SÜRDÜRÜLEBİLİR PROTEİN KAYNAĞI OLARAK YENİLEBİLİR BÖCEKLERİN BESLEYİCI ÖZELLİKLERİ ve TÜKETİCİ KABULÜ
}

\author{
Burak Erdoğan, Ayşe Görür, Doğa Peksever*, Ogeday Sümer, Sedef Nehir El \\ Ege Üniversitesi, Mühendislik Fakültesi, Gıda Mühendisliği Bölümü, Beslenme Bilim Dalı, İzmir, Türkiye \\ Geliş / Received: 14.04.2021; Kabul / Accepted: 15.07.2021; Online bask1 / Published online: 06.08.2021
}

Erdoğan, B., Görür, A., Peksever, D., Sümer, O., El Nehir, S. (2021). Sürdürülebilir protein kaynağ1 olarak yenilebilir böceklerin besleyici özellikleri ve tüketici kabulü. GIDA (2021) 46 (5) 1105-1116 doi: 10.15237/gida. GD21074.

Erdoğan, B., Görür, A., Peksever, D., Sümer, O., El Nebir, S. (2021). Nutritional value and consumer acceptance edible insects as a sustainable source of protein. GIDA (2021) 46 (5) 1105-1116 doi: 10.15237/gida. GD21074.

\section{ÖZ}

Nüfus artısı, tarım alanlarının yetersizliği ve iklim değişiklikleri gibi sorunlar nedeniyle, gıda kaynaklarının sürdürülebilirliği giderek önem kazanmaktadır. Gelecekte özellikle protein gereksiniminin karşılanması temel bir sorun olarak öngörülmektedir. Yenilebilir böcekler geleneksel protein kaynakları ile kıyaslandığında üretimlerindeki avantajlar nedeniyle sürdürülebilir gıda kaynakları olarak değerlendirilmektedir. Güney Amerika ülkeleri ve Çin gibi ülkelerde geleneksel olarak tüketilen ancak batı toplumlarında neofobi ve tiksinme nedeniyle kabul görmezken bütün formu yerine un formunda kullanılması entomofajiyi uygulamak için umut verici bir seçenek olarak görülmektedir. Yenilebilir böceklerin, besleyici özellikleri ile antidiyabetik ve antimikrobiyel gibi potansiyel etkileriyle sağlık üzerine faydalarının incelendiği çalışmalar artmaktayken toksik ve alerjik etkileri üzerine çalışmalar halen yetersizdir. Yenilebilir böceklerin, özellikle Avrupa Gıda Güvenliği Kurumu'nun (European Food and Safety Authority, EFSA) 2021 yll başında yayınladığ1 sarı un kurdunun gida olarak tüketilmesini onaylayan yönetmelik ile yenilebilir böceklerin bilim dünyasında daha fazla konu olacağı düşünülmektedir.

Anahtar kelimeler: sürdürülebilir gıda, böcek, sağl1k etkileri, tüketici alg1s1

\section{NUTRITIONAL VALUE AND CONSUMER ACCEPTANCE EDIBLE INSECTS AS A SUSTAINABLE SOURCE OF PROTEIN}

\begin{abstract}
As a result of world population growth, scarcity of agricultural land and climate change, the importance of sustainable resources is increasing. In the future, people's need for sustainable protein sources will be a problem globally. Edible insects are one of the sustainable protein sources that have advantages compared to traditional ones. They are traditionally consumed in countries such as South American countries and China but are not accepted due to neophobia and disgust in western societies. Their use in flour form is seen as a promising option for implementing entomophagy. Studies on their nutritional benefits and potential effects such as antidiabetic and antimicrobial are increasing
\end{abstract}

\section{${ }^{*}$ Yazışmalardan sorumlu yazar / Corresponding author}

1 dogapeksever@gmail.com

(ग): (+90) 5301316883

Burak Erdoğan; ORCID no: 0000-0001-6135-6770

Ayşe Görür; ORCID no: 0000-0002-5507-0490

Doğa Peksever; ORCID no: 0000-0003-2719-2412

Ogeday Sümer; ORCID no: 0000-0002-9541-9212

Sedef Nehir El; ORCID no: 0000-0002-2996-0537 
while studies on their toxicity and allergenicity are still insufficient. It is thought that studies on edible insects will gradually increase with the regulation of approving the consumption of yellow mealworm as food published by the European Food Safety Authority (EFSA) in early 2021.

Keywords: sustainable food, insects, health effects, consumer perception

\section{GİRIŞ}

Dünya nüfusunun 2030'a kadar yaklaşık 8.5 milyar, 2050'ye kadar ise 9.8 milyar olacağ1 ön görülürken, gida talebinde de 2050'ye kadar büyük bir artış olacağı belirtilmektedir (UN, 2017). Aynı zamanda et ve et ürünlerine olan talebin 2050 yilında 455 milyon tona ulaşabileceği düşünülmektedir. Bu da 2005 ve 2007'de raporlanan et tüketiminden $\% 76$ oranında daha fazla olacağı anlamındadır (Ravi vd., 2020). Dünya topraklarının şu anda \%40'1 gıda üretmek için kullanılmasına karşın tarım ve otlak alanlarda kıtlık yaşanmaktadır. Tüm bu öngörüler ile gıdanın yeterliliği için sürdürülebilir stratejilere ihtiyaç vardır (Nissen vd., 2020).

Sürdürülebilirlik kavramı, insan faaliyetlerinin ve çevrenin uyumlu bir şekilde bir arada olması için en uygun koşulları belirleme durumu ile ilişkilendirilir. Sürdürülebilirlik, çevre kirliliğinden endüstriyel üretime, arazilerin kötüye kullanımına, demografik krize, atık yönetimine kadar uzanan sorunların çoğunu kapsamaktadır (Cadinu vd., 2020). G1da üretimi kirliliğe yol açmakta ve insan sağlı̆ı üzerinde zararlı etkileri olan reaktif azot bileşikleri, sera gazları, antibiyotikler, pestisitler ve biyolojik ajanlar gibi birçok sorunu da beraberinde getirmektedir. G1da üretiminin getirdiği bu sorunlarla beraber, toprak kalitesinin gittikçe azalması ve erozyon ile toprak kaybı gibi sorunlar da ortaya çıkmaktadır (Aiking ve de Boer, 2020). Sürdürülebilir olmayan tarım uygulamaları, ormansizlaşma, su kitlığı, kentleşme ve iklim değişikliği gibi nedenler ekilebilir alanların hızla tükenmesine sebep olmaktadır. Sürdürülebilir uygulamalara geçmek, gida üretim sistemleri üzerindeki yükü hafifletebilecek çözümün temelini oluşturmaktadır (Ravi vd. 2020).

Yenilebilir böcekler, geleneksel hayvansal gidalara alternatif olarak artan bir ilgi ile yüksek kaliteli proteinlerin yeni bir kaynağını temsil etmektedir. Çekirge, cırcır böceği, termit ve un kurdu gibi böceklerden elde edilen proteinler; büyükbaş ve kümes hayvanları gibi protein kaynaklarına göre pratik ve uygun maliyetli bir alternatif olarak popüler hale gelmeye başlamıştır (de Castro vd., 2018; Nissen vd., 2020). Ayrıca çevresel açıdan, geleneksel protein kaynaklarına kıyasla $1 \mathrm{~kg}$ böcek proteini üretimi daha az alan gerektirmekte, daha az sera gazı emisyonuna neden olmakta ve organik atıkların yüksek değerli biyolojik ürünlere dönüştürülmesini içermektedir (Ravi vd., 2020).

Gıda ve Tarım Örgütü (FAO) tarafindan 2013 yılında, "Yenilebilir Böcekler: Gıda ve Yem Güvenliği için Gelecek Beklentileri” başlığıyla yayınlanmış raporda, böcek tüketiminin kapsamlı bir analizi sunulmuş ve yenilebilir böceklerin gelecekte sürdürülebilir bir gida kaynağ1 olacağ1 savunulmuştur (van Huis vd., 2013). Raporla birlikte tüketicilerin ve medyanın yenilebilir böceklere olan ilgisi artmıştır (Wade ve Hoelle, 2020). Son olarak Avrupa G1da Güvenliği Kurumu'nun (EFSA) 2021 yllinın ilk ayında yayınlamış olduğu yönetmelikle sarı un kurdunun tüketimini onaylamas1 (EFSA, 2021), yakın zamanda böcek tüketiminin hayatımızda daha fazla yer alacağını ortaya koymaktadır.

Böcek tüketimi olarak adlandırılan entomofaji aslında dünyanın pek çok ülkesi için yeni bir kavram değildir. Karınca ve böcek larvaları Afrika ve Avustralya'daki kabilelerin diyetlerinde önemli bir parçayken, Tayland'da ise kızartılmış böcekler sevilen ve popüler gıdalardır. Dünya çapında en az 2 milyar insan tarafindan düzenli olarak böcek tüketildiği tahmin edilmektedir. Literatürde çoğu tropikal ülkelerde olmak üzere 1900'den fazla böcek türünün yenilebilir olduğu belgelenmiştir (van Huis vd., 2013). Yenilebilir böceklerin giderek popüler hale gelmesine; gida k1tlı̆ı durumunda kurtarıcı olarak değerlendirilebileceği yaklaşımı neden olmuştur. Aynı zamanda sürdürülebilir bir kaynak olarak böcek tüketimini teşvik etmedeki temel zorluklardan biri, böcekleri tüketicilerin gözünde çekici ve lezzetli hale getirmektir (Zielińska ve Pankiewicz, 2020; Ordoñez-Araque ve Egas-Montenegro, 2021). 
Son yıllarda yenilebilir böcekler üzerinde yapılan çalışmaların önemli ölçüde arttı̆̆1, besleyici değerleri, sağlık üzerine etkilerinin yanı sıra riskleri ve tüketici kabulü üzerine de yoğunlaştığ 1 görülmektedir. $\mathrm{Bu}$ derlemede, çalışmalar ilgili başlıklar ile değerlendirilerek incelenmiştir.

\section{YENİLEBİLİR BÖCEKLER VE BESLEYICİ ÖZELLİKLERİ}

Yenilebilir böceklerin besleyici özellikleri oldukça değişkendir. Aynı böcek türünde böceğin metamorfik aşamasına (yumurta, larva, pupa ve yetişkin) ve yaşam alanları ile diyetlerine bağlı olarak farklılık gösterebilir. Böcekler genel olarak protein ile tekli ve çoklu doymamış yă asitleri bakımından zengin oldukları için besleyici değerleri açısından önemli bir yere sahiptirler (Bessa vd., 2020). Böceklerin küresel protein gereksiniminin karşılanması ile ilgili sorunu çözmek için en umut verici alternatif kaynaklardan biri olmasının sebebi diğer protein kaynaklarına göre yüksek protein içeriğine, amino asit bileşimine ve düşük çevresel üretim maliyetine sahip olmasıdır (Jantzen da Silva Lucas vd., 2020).

Böceklerin besin öğeleri bileşimi birbirlerinden farkl11ık gösterebilmektedir. Örneğin türler arasında protein içeriklerindeki farklıllğın, yetişme koşulları, farklı diyetler veya hasat aşamalarından kaynaklanabileceği bildirilmiştir. Protein içerikleri farklılaşma evrelerine ve yapılan protein analiz yöntemlerine göre de değişiklikler göstermektedir (Boulos, Tännler ve Nyström, 2020; Jonas-Levi ve Martinez, 2017). Böcek proteinlerinin sindirilirliğinin araştırıldığı çalışmalarda, cırcır böceği (Gryllodes sigillatus) proteinin in vitro protein sindirilirliğinin \% $\% 6.2$, un kurdu (Tenebrio molitor) proteinin ise \%75.7 olduğu saptanmıştır (Stone vd., 2019). Çizelge 1'de bazı yenilebilir böcek türlerinin protein içerikleri, Çizelge 2'de ise sürdürülebilir protein kaynaklarından olan bazı bitki, alg ve mantar türlerinin protein içerikleri verilmiştir.

Çizelge 1. Bazı yenebilir böcek türlerinin protein içerikleri (Nongonierma ve FitzGerald, 2017)

\begin{tabular}{|c|c|c|c|}
\hline Bilimsel isim & Yaygin isim & $\begin{array}{l}\text { Protein içeriği } \\
(\%)\end{array}$ & Kaynak \\
\hline Gryllodes sigillatus & Şeritli cırcir & 70.00 & (Zielińska vd., 2015) \\
\hline Acheta domesticus & Ev cırcır böceği & $55.00-70.75$ & $\begin{array}{l}\text { (Rumpold ve Schlüter, } \\
\text { 2013) }\end{array}$ \\
\hline Schistocerca gregaria & Çöl çekirgesi & 76.00 & (Zielińska vd., 2015) \\
\hline Ruspolia differens & Çekirge & $43.10-44.30$ & $\begin{array}{l}\text { (Rumpold ve Schlüter, } \\
\text { 2013) }\end{array}$ \\
\hline Tenebrio molitor & Sarı un kurdu & $47.18-60.20$ & $\begin{array}{l}\text { (Rumpold ve Schlüter, } \\
\text { 2013) }\end{array}$ \\
\hline Zophobas morio & Büyük solucan & $43.13-46.79$ & $\begin{array}{l}\text { (Rumpold ve Schlüter, } \\
\text { 2013) }\end{array}$ \\
\hline Alphitobius diaperinus & Küçük un kurdu & 58.03 & (Yi vd., 2013) \\
\hline Bombycidae mori & İpek böceği & $48.70-69.84$ & $\begin{array}{l}\text { (Rumpold ve Schlüter, } \\
\text { 2013) }\end{array}$ \\
\hline Samia ricinii & Eri ipek böceği & $54.00-54.80$ & $\begin{array}{l}\text { (Rumpold ve Schlüter, } \\
\text { 2013) }\end{array}$ \\
\hline Blaptica dubia & Arjantin hamam böceği & 59.2 & (Yi vd., 2013) \\
\hline Gromphadorbina portentosa & Madagaskar hamam böceği & $62.52-63.35$ & $\begin{array}{ll}\text { (Oonincx } & \text { ve } \\
\text { Dierenfeld, 2012) }\end{array}$ \\
\hline Macrotermes subbylanus & Termit & 39.34 & (Kinyuru vd., 2013) \\
\hline
\end{tabular}


Çizelge 2. Bazı sürdürülebilir protein kaynaklarının protein içerikleri (Fasolin vd., 2019)

\begin{tabular}{|c|c|c|c|}
\hline Tür & Bilimsel isim & Protein içeriği $(\%)$ & Kaynak \\
\hline Bitki & Amaranthus spp. & $12.5-17.6$ & (Caselato-Sousa ve Amaya-Farfán, 2012) \\
\hline Bitki & Chenopodium quinoa Willd & $12-23$ & (Ruiz vd., 2016) \\
\hline $\mathrm{Alg}$ & $\begin{array}{l}\text { Arthrospira platensis } \\
\text { (Spirulina platensis) }\end{array}$ & 53.5 & (Benelhadj vd., 2016) \\
\hline $\mathrm{Alg}$ & Chlorella vulgaris & $12.7-53.0$ & (Laurens vd., 2017; Ursu vd., 2014) \\
\hline Mantar & Aspergillus niger & $10.3-61.2$ & (Kamal vd., 2019) \\
\hline Mantar & Fusarium venenatum & $41.8-46.4$ & (Hosseini ve Khosravi-Darani, 2011) \\
\hline
\end{tabular}

Lipit içeriği, yenilebilir böceklerde yaşamlarının larva aşamasında daha yüksektir. Triaçilgliseroller yağ içeriğinin yaklaşık \%80'ini oluşturur ve bunu yaşam evresine göre değişebilen $\% 20$ 'den azını temsil eden fosfolipitler izlemektedir (de Castro vd., 2018). Un kurtlarındaki doymamış yağ asitlerinden omega-3 ve omega-6 yağ asitleri bileşiminin sığır ve domuzda bulunan değerlerden yüksek olduğu saptanmıştır. Böceklerdeki karbonhidratlar çoğunlukla kitin içinde bulunur ve kuru ağırlığın \%5-20'sini oluşturur. Yenilebilir böceklerdeki karbonhidrat içeriği kalkan böceğinde \%6.71'den ağustos böceklerinde \%15.98'e kadar değişmektedir (Govorushko, 2019). Böceklerin sağladığı enerji değeri de böcek türleri arasında değişiklik gösterir ve türe bağlı olarak $100 \mathrm{~g}$ kuru madde için 293 ile $776 \mathrm{kcal}$ arasında değişmektedir. Meksika'nın Chiapas Eyaleti'nde bin başlı yllan (Latebraria amphipyrioides) olarak bilinen solucanın 100 g'1 349 kcal sağlarken, çekirgenin (Acrida exaltata) 100 g'1 $336.93 \mathrm{kcal}$ ve Meksika güvesinin (Phassus triangularis) 100 g'1 $761 \mathrm{kcal}$ enerji sağlamaktadır (Ordoñez-Araque ve Egas-Montenegro, 2021).

Yenilebilir böceklerin vitamin ve mineral değerleri incelendiğinde; çekirge, cırcır böceği, termit ve un kurtlar1 gibi böcekler demir, çinko, kalsiyum, bakır, fosfor, magnezyum ve manganez açısından zengindir (de Castro vd., 2018). Tavuk ve sığır eti; $100 \mathrm{~g}$ ağırlık başına sırasıyla sadece 1.2 ve $3 \mathrm{mg}$ demir minerali sağlarken, palmiye böcekleri (Rhynchophorus phoenicis) veya tırtllar (Imbrasia belina), $100 \mathrm{~g}$ ağırlık başına sırasıyla 12 ve $31 \mathrm{mg}$ demir minerali sağlayabilmektedir. Çinko ise genellikle böceklerin çoğunda bulunan bir mineraldir. Örneğin palmiye kurdu (Rhynchophorus phoenicis) larvalarının $100 \mathrm{~g}$ 'da $26.5 \mathrm{mg}$ çinko vardır (Tao ve Li, 2018).

Yenilebilir böceklerin besleyici değerleri göz önüne alındığında, FAO'nun öngördüğü, besin öğelerinin günlük gereksinimlerinin böcekler ile karşılanacağı anlaşılmaktadır. Örneğin $100 \mathrm{~g}$ tırtıl böceği tüketimi ile, günlük protein gereksiniminin \%76's1 sağlamaktayken sadece 3 tane ipek böceği pupas1, 1 adet tavuk yumurtası kadar besin değeri açısından zengin kabul edilmekte ve bileşimi yaklaşı1k \%50 protein ile \%30 lipitten oluşmaktadır (Jantzen da Silva Lucas vd., 2020; Bessa vd., 2020). Tüm bu veriler sonucunda yenilebilir böceklerin makro ve mikro besinlerden zengin olduğu ve sürdürülebilir bir protein kaynağ1 olarak umut vadettiği sonucuna varılmaktadır.

\section{YENİLEBİLİR BÖCEKLERİN POTANSIYYEL SAĞLIK ETKİLERİ VE RİSKLERİ \\ Prebiyotik Etki}

İnsan sindirim sisteminde bitkisel gidaların sindirilemeyen ve ince bağırsaktan emilmeyerek, kalın bağırsağa geçen kısımları mikrobiyota için birincil enerji kaynağıdır. Diyet lifinin sağlık üzerine kanıtlanmış birçok etkisi, yenilebilir böceklerin içerdiği diyet lifi kaynăg kitin fraksiyonu için de geçerlidir. Yenilebilir böceklerin bağırsak florasına etkisi üzerine yapilan bir çalışmada günde $25 \mathrm{~g}$ cırcır böceği (Gryllodes sigillatus) unu tüketen kişilerin dişk1 örneklerinde probiyotik bakterilerden Bifidobacterium animalis türünde 5.7 kat artı̧s saptanmıştır (Stull vd., 2018). Sar1 un kurdunun (Tenebrio molitor) prebiyotik etkisini saptamak amacı ile yapılan bir çalışmada ise Lactobacillus ve Bifidobacterium türleri üzerinde 
olumlu etki ederek mikrobiyatanın iyi yönde gelişmesini sağladığ1 saptanmıştır (de Carvalho vd., 2019). Böcek lifinin probiyotiklerin gelişmesini sağlaması sebebi ile prebiyotik etki gösterdiği düşünülmekteyken böceklerde bulunan ve sindirilmeden kalın bağırsağa geçebilen diğer besinler açısından da prebiyotik etki konusunda çalışmalar yapılması gerekmektedir.

\section{Antiinflamatuar Etki}

Gryllus bimaculatus türü cırcır böceklerinde glikosaminoglukan adı verilen bir çeşit polisakkaritin, fare modellerinde önemli düzeyde antiinflamatuar etki gösterdiği bildirilmiştir. Antiinflamatuar özellikleri glikosaminoglukan polisakkaritinin bu farelerde bulunan inflamatuar biyolojik belirleyicilerden olan C-reaktif protein (CRP) molekülü, IL-6 ve romatoit faktörünün aktivitesinin engellenmesi sonucu görülmektedir (Ahn vd., 2014). Ayrıca yüksek yağ içerikli diyet uygulanmış farelere verilen glikosaminoglukanın, farelerin yă̆ dokusu, CRP seviyesi, kan kolesterolü ve karaciğer yağ düzeyinde zamanla azalma sağladığ1 saptanmıştır (Ahn vd., 2016). Diyabetik farelerde glikozaminoglikan takviyesini içeren başka bir çalışma, glikozaminoglikan tedavisi alan diyabetik farelerin kan glukozu ve LDL-kolesterol seviyelerinde bir azalma ve antioksidan enzimlerin aktivitesinde bir artış olduğunu saptamıştır (Ahn vd., 2020). Bu çalışmalar 1şı̆̆ında böcekte bulunan glikosaminoglukanın inflamasyon belirteçleri, kolesterol ve kan glikozu üzerinde olumlu etkiler sağlayabileceği sonucu çıkarılmaktadır.

Böceklerden elde edilen protein hidrolizatlarının insan sağllğı üzerine olumlu etkileri olan peptitlerin kaynağ1 olduğu bildirilmiştir (Nongonierma ve FitzGerald 2017). Pamuk yaprak kurdu, ipek böceği, çöl çekirgesi ve yaban arısından elde edilen biyoaktif peptit içeren protein hidrolizatlarının farelerdeki hipertansiyonu azalttığ1 saptanmıştır. Bu etkiyi kan damarlarını daraltarak kan basıncinın yükselmesine sebep olan anjiyo tensin dönüştürücü enzim aktivitesini (ACE) engelleyen peptit yapılarının sağladığı bildirilmiştir (Vercruysse vd. 2005). Başka bir çalışmada ise yenilebilir tropikal ev böcekleri, un kurdu ve çöl çekirgesinden elde edilen protein hidrolizatlarının antiinflamatuar etki gösterdiği belirtilmiştir. $\mathrm{Bu}$ etki inflamatuar işaretleyicilerden olan lipoksigenaz ve sislooksigenaz aktivitelerinin engellenmesi sonucunda gerçekleşmekte ve en yüksek etkinin çöl çekirgelerinden elde edilen protein fraksiyonlar1 olduğu saptanmıştır (Zielińska vd., 2017). Yapilan bu çalışmalar sonucunda böceklerden elde edilen biyoaktif peptitlerin kardiyovasküler ve inflamatuar hastalıklar üzerinde olumlu etki gösterebileceği sonucu çıkarılmaktadır.

\section{Antioksidan ve Antimikrobiyel Etki}

Antioksidan etki gösteren bileşikler yenilebilir böcek türleri içerisinde bulunabilmekte veya bu kaynaklardan elde edilen biyoaktif bileşikler sayesinde de antioksidatif etki sağlanabilmektedir. Yenilebilir böcek türlerine uygulanan enzimatik hidroliz sonucu oluşan peptit fraksiyonlarının oksidatif strese neden olan serbest radikal konsantrasyonunu azalttı̆̆1 gösterilmiştir. On iki çeşit yenilebilir böcek ve iki çeşit omurgasızdan elde edilen su ve yağda çözünür ekstraktların in vitro antioksidan etkisini araştıran bir çalışmada çekirge, ipek böceği ve cırcır böceğinin taze portakal suyundan 5 kat daha yüksek antioksidan kapasiteye sahip olduğu saptanmıstır (Di Mattia vd., 2019). Böcek proteinlerinin hidrolizi sonucu oluşan peptit fraksiyonlarının etkilediği antioksidan mekanizmaları hala tam olarak bilinmemektedir. Ancak böcek proteinlerinin aminoasit içerikleri ve dizilimlerindeki değişkenlik biyoaktif peptitlerin muhtemel antioksidan etkilerinin farklı düzeyde olmasına neden olmaktadır (Sarmadi ve Ismail, 2010). Baz1 çalışmalarda ise aromatik aminoasitler ile hidrofobik özellik gösteren aminoasitlerin daha fazla antioksidan aktivite gösterdiği belirtilmektedir (Najafian ve Babji, 2012; Chalamaiah vd., 2012; Da Rocha vd., 2018).

Yenilebilir böceklerin içerdiği proteinlerin hidrolizlenmesi ile antimikrobiyel etkiye sahip peptitler izole edilmiştir. Böceklerin antimikrobiyel peptitlerinin (çekropinler ve attasinler) yaklaş1k 30-60 aminoasit zincirinden oluştuğu ve bazı koşullarda $\left(100^{\circ} \mathrm{C}, 15\right.$ dakika) stabil kalabildiği saptanmıştır (Jantzen da Silva 
Lucas vd., 2020). Antimikrobiyel peptitler izole edildiği böcek türüne göre farkll1ık göstermekte ve bu peptitler farklı biyoaktivite gösterebilmektedirler (de Castro vd., 2018; Rahnamaeian vd., 2015). Yapılan bir çalışmada yaban arilarından izole edilen abaesin (prolin aminoasitince zengin) ve himenoptaesin (glisin aminoasitince zengin) peptitlerinin patojen Escherichia coli üzerine etkisi araştırılmıştır. Bulgularda abaesinin tek başına $200 \mu \mathrm{M}$ konsantrasyonda uygulandığında herhangi bir antimikrobiyel etkisi gözlemlenmezken, himenoptaesin $2 \mu \mathrm{M}$ ve daha yüksek konsantrasyonlarda uygulandığında anlamlı bir antimikrobiyel etki gösterdiği saptanmıştır (Rahnamaeian vd., 2015). Yenilebilir böceklerin içerdiği biyoaktif bileşiklerin potansiyel biyoaktiviteleri üzerine çalışmaların devam etmesi gerektiği düşünülmektedir.

\section{Antidiyabetik Etki}

Bazı yenilebilir böcek protein hidrolizatlarının karbonhidrat sindirim enzimi alfa-glukosidazın inhibisyonu üzerinde etkili olduğu ve antidiyabetik etki gösterdiği saptanmıştır (Jung vd., 2010; Han vd., 2016). Bu konuda yapılan in vitro bir çalısmada ipek böceğinden izole edilen peptitlerin alfa-glukosidaz enziminin aktivitesini inhibe ederek karbonhidrat sindirimini azalttı̆̆ belirtilmiştir (Nongonierma ve FitzGerald, 2017). Ancak bu konuda in vivo ve in vitro çalışmalar yeterli değildir ve potansiyel antidiyabetik etkinin hangi biyoaktif bileşikten/bileşiklerden kaynaklandığının tespiti ve mekanizmasının belirlenmesi için daha fazla çalışmaya gereksinim vardir.

Yenilebilir böcekler içeriklerindeki vitamin, mineral, lif, zorunlu amino asitler, omega-3 ve omega-6 yağ asitleri ve antioksidan bileșenler sayesinde sağlık yararlarına sahip olabilmektedir. Gelecekteki araştırmalar, böceklerin veya böceklerden elde edilen izolatlarının geleneksel hayvan ve bitki bazlı gidalara kıyasla faydalı etkilerini anlamayı amaçlamalıdır (Nowakowski vd., 2021).

Yenilebilir böceklerin sağllk etkileri üzerine yapılan in vivo ve in vitro çalışmalar giderek artarken insan çalışmaları oldukça azdır. Bu sebeple sağlık etkileri üzerine yapılan insan çalışmalarını artırmak amaçlanmalıdır.

\section{Yenilebilir Böceklerin Pestisit Yükleri ve Alerjik Özellikleri}

Böceklerin insan beslenmesinde yaygin olarak kullanılabilmesi için gıda güvenliği endişelerinin; özellikle de potansiyel risklerin giderilmesi çok önemlidir (van der Fels-Klerx vd., 2018). Doğal çevreden toplanan ya da çiftliklerde üretilen yenilebilir böceklerdeki kimyasal kontaminantlar sorunu gida güvenliği konusunda önemli bir tehdittir. Yenilebilir böceklerin pestisit türevli kimyasallara maruz kalmalarının sebepleri, böceklerin sabit kalmayıp bir yerden başka bir yere sürekli hareket halinde olması ve pestisit kullanılmış bitkileri tüketmesi veya pestisit kullanımı esnasında o alanda bulunmalarıdır. Böceklere bulaşabilen bu pestisit kontaminasyonu ile ilgili bir çalışmada, Kuveyt'de piyasadaki yenilebilir bir böcek türünde oldukça yüksek pestisit konsantrasyonlar1 $(49.2 \mu \mathrm{g} / \mathrm{kg}$ organik klor ve $740.6 \mu \mathrm{g} / \mathrm{kg}$ organofosfor) saptanmışır (Imathiu, 2020). Ancak gelişen teknolojiyle birlikte yenilebilir böcek üretimi yapılan yerlerde böceklerin beslenmesinin kontrol altına alınması mümkündür. Pestisit türevli maddelerin böceklerdeki biyolojik birikimi üzerine yapılan bir çalışmada ise pestisitler (benzaton, bifentirin izoproturon ve mefanoksam, linuron, pendimetalin, primetani, tebukonazol, 2,4-D, klopiralid, diflufenikan ve fenpropimorf) ile muamele edilen havuç ile beslenen sarı un kurdunda biriken ve birikmesi sonucu dişarı salınan pestisit miktarı ölçülmüş ve fenpropimorf birikiminin en yüksek olduğu, ancak biriken bu maddenin salınımının ise en az olduğu belirtilmiştir (Poma vd., 2017). Bu konuda araştırmalar hassasiyetle devam etmeli ve güvenilir tüketimin sağlanabilmesi için kesinlik kazanmalıdır.

Böcekler; kabuklular gibi eklembacaklılar ailesine aittir. Kabuklu alerjileri yaygin ve potansiyel olarak şiddetli alerjilerdir. Bu nedenle, kabuklu alerjisi olan bireylerde bağışıklık sistemi böcek proteinlerine karşı çapraz reaktivite geliştirerek potansiyel bir sağlık sorunu yaratabileceği oldukça 
nettir. Aynı zamanda ev tozu akarlarına karşı immünolojik yanıt veren bireylerde de duyarlılık olabileceği gösterilmesine karşın klinik önemi ve moleküler mekanizmaları henüz net değildir (Ribeiro vd., 2021). Böcek alerjisinin altında yatan moleküler mekanizmalar hakkında daha fazla bilgiye ihtiyaç duyulmaktayken yapılan çalışmalara göre böcek türlerinde bulunan arjinin kinaz, serisin ve tropomiyosinin alerjik yapidaki proteinler olarak belirlenmiştir (Bose vd., 2021; Hall ve Liceaga, 2020; Liu vd., 2006; Murefu vd., 2019; Ribeiro vd., 2018). Alerjenite çalışmaları devam ederken sadece 1sısal işlemlerin alerjeniteyi azaltmada yetersiz kaldığı, fakat isısal işlemlerle birleştirilmiş enzimatik hidroliz gibi özel işlemlerin yenilebilir böceklerin IgE-reaktivitesini ortadan kaldırarak alerjeniteyi azaltabileceği saptanmıştır (Ribeiro vd., 2021). Böcek türlerinde bulunabilen alerjik bileşiklerin yenilebilir her böcek türü için çok iyi belirlenmesi ve bu türlerde alerjeniteyi azaltmak için hangi işlemlerin uygulanabileceğinin araştırılması gereklidir ve son olarak ürün ambalajlarında alerjen uyarısı mutlaka yapılmalidır.

\section{YENILLEBİLİR BÖCEKLER TÜKETİCİ KABULÜ VE ALGISI}

İÇİN

Birçok yenilebilir böcek türü, geleneksel olarak çok eski zamanlardan beri birçok kültür tarafından; bütün veya bir bileşen olarak çeşitli g1da ürünlerine dahil edilerek tüketilmektedir. Yenilebilir böcekler, besleyici özellikleri ve sağlık üzerine olumlu etkilerine rağmen, gelişmiş ülkelerde, nüfusun çoğunluğu tarafından tüketici kabulünü sağlamış değillerdir. Böceklerden tiksinilmesi onların protein kaynağ1 olarak değerlendirilmesinin önündeki önemli engellerden biridir (Imathiu, 2020).

Yenilebilir böceklerin tüketici kabulü üzerine ülkelerin kıyaslandığı çalışmalarda; Çinliler, bütün haldeki böcek içeren gidaları tat, besleyici değeri ve sosyal kabul açısından Almanlara kiyasla daha olumlu değerlendirmekte ve böcek içeren gidaları tüketmeye daha fazla istekli olduğu bulunmuştur (Hartmann vd., 2015). Kuzey Avrupa ülkelerindeki tüketicilerin genellikle Orta Avrupa'daki tüketicilere göre böcek tüketmeye karşı daha olumlu bir tutuma sahip oldukları saptanmıştır (Piha vd., 2018). Entomofajinin kabulü ve popülaritesi ile böcek içeren gıdaları tüketme isteği kültüre, yaşanılan bölgeye ve daha önceki tüketim düzeyine bağlı olduğundan ülkeler arasında önemli ölçüde farklılık gösterirken, faydalarını biliyor olmak, daha önce bu gıdaları denemiş olmak, tüketim formu (bütün, un vb.) ve böcek türü bireyler arasında tüketme istekliliğini etkileyen faktörler olarak sayılmaktadır (SunWaterhouse vd., 2016; Woolf vd., 2019; Higa vd., 2020).

Hem Amerika'da hem de Hindistan'da yaşayan kişilerde yapılan ankette, 'tiksinme' böcek yemeye karşı en yaygin tutum olarak belirlenirken, yine her iki ülkede de farklı tür böcekler arasında karınca en lezzetli, hamam böceği ise en tatsız olarak seçilmiştir. Katılımcilar en sevdikleri gidalarda düşük seviyelerde yenilebilir böceklerin un formunda kullanılmasını tüketim açısından kabul etmişlerdir (Ruby vd., 2015). Başka bir çalışmada ise Amerikalıların böcek tüketiminde Hintlilerden daha istekli olduğu ve erkeklerin de kadınlardan daha istekli olduğu saptanmıştır. Her iki grupta da "tiksinme" tepkisi en belirgin tutumken, Amerikalılarda "faydaları", Hintlilerde ise "dini inanç" yeme istekliliğini belirleyici faktör olarak takip etmiştir (Ruby vd., 2019). Benzer olarak İtalyan tüketicilerde de erkeklerin kadınlardan daha istekli olduğu, tiksinme ve gida neofobisinin böcek yemeyi reddetmedeki ana faktörleri temsil ettiği, belirtilen türler arasında ise en çok tercih edilenin cırcır böceği olduğu saptanmış ve yapılan duyusal değerlendirmede; düşük seviyede böcek görünürlüğü olan gidaların tercih edildiği ortaya koyulmuştur (Tuccillo vd., 2020). Alman tüketiciler böcek tüketimini, böceklerin çevre dostu bir üretime sahip olmaları ve olumlu sağllk etkileri göstermeleri sebebi ile tercih etmekteyken, tiksinme ve isteksizlik gibi nedenler böcek tüketimlerini kötü yönde etkilemektedir (Kornher vd., 2019). Uluslararası bir çalışmada böcek unu içeren yeni bir gidayı deneme istekliliği 13 farklı ülke için değerlendirildiğinde, 8 ülkeden katılımcıların tiksinme sebebiyle istekli olmadıkları saptanmıştır. Ülkelerin çoğunda sadece böceklerin hastalık taşıdığı alg1sı belirginken, bireylerin böcek unu içeren gidaları tüketmeyi istememelerinin nedenleri din, böceklerin hastalık taşımaları ve 
alerjik reaksiyonlara neden olabilecekleri algis1 olarak belirlenmiştir (Castro ve Chambers IV, 2019). Ülkemizde ise gençlerde entomofajinin diğer çalışmalara benzer olarak cinsiyetten etkilendiği saptanırken, entomofajiyi reddetme nedenleri arasında en çok belirtilen neden tiksinme olarak saptanmıştır (Yüksel ve Canhilal, 2018). Bu veriler ile; kültürler ve bireyler arasında inanç ve tutum farklilıklarının, böcek türü ve tüketim formunun tercih nedeni olabileceği, g1da içerisinde böcek görünürlüğü ile cinsiyetler aras1 böcek tüketme istekliliğinin benzerlikler ve farklılık gösterebildiği sonucuna varılmaktadır. Böcek veya böcek içeren głda tüketme istekliliği; tiksinme, hastallk veya alerjiye sebep olabilme düşüncesi gibi farklı tutum ve inançlar sebebiyle azalabilmekte, daha önce denemiş olmak, gıdalara böcek unu olarak eklemek ve böcekler hakkında bilgi düzeyinin yüksek olması istekliliği artırmaktadır. Bu sebeple istekliliği artırmak için böcek için g1da güvenliği konusunda daha fazla araştırma yapılması, toplumlara uygun gidaların geliştirilmesi ve bireylerin bilgi düzeyinin artırilmasi gerekmektedir.

\section{SONUÇ}

Dünya nüfusunda beklenen artış hızı, doğal kaynakların tükenme riski ve özellikle protein kaynaklarının yetersizlĭgi gibi konular gelecekte karşılaşılacak sorunlar olarak öngörülmektedir. Bu durumda sürdürülebilir gıda konusunda çözüm üretme arayışları için yüksek miktarda protein içeriğine ve kaliteli aminoasit bileşimine sahip yenilebilir böcekler; gelecekte protein gereksiniminin karşılanması için oldukça umut verici görülmektedir. Aynı zamanda besleyici özellikleri ile antioksidatif, antimikrobiyel, antiinflamatuvar etkileri yenilebilir böceklerin sağlık üzerine olumlu potansiyelini arttırmaktadır. Sağlık faydalarının yanında yenilebilir böceklerin insanlar tarafindan tüketim istekliliği cinsiyet, inanç ve kültür gibi birçok etkene bağlı olarak değişkenlik gösterebilmektedir. Yenilebilir böceklerin besleyicilik ve potansiyel sağllk etkisi çalışmalarının, toksitite ve alerjenite gibi gida güvenlik çalışmalarının, aynı zamanda tüketicilerin tüketim istekliliğinin arttırılmasına yönelik çalışmaların yapılmasına ihtiyaç vardır.

\section{ÇIKAR ÇATIŞMASI BEYANI}

Yazarların, başka kişiler ve/veya kurumlar ile çıkar çatışması bulunmamaktadır.

\section{YAZAR KATKILARI}

Tüm yazarlar makalenin yazilmasinda ve yayınlanmasında eşit katkı sağlamışlardır. Makalenin hazırlanmasında başka kişi ve/veya kurumların katkısı yoktur.

\section{KAYNAKÇA}

Ahn, M. Y., Han, J. W., Hwang, J. S., Yun, E. Y Lee, B. M. (2014). Anti-inflammatory effect of glycosaminoglycan derived from Gryllus bimaculatus (a type of cricket, insect) on adjuvanttreated chronic arthritis rat model. J Toxicol Environ Health Part A, 77(22-24), 1332-1345. doi:10.1080/15287394.2014.951591

Ahn, M. Y., Hwang, J. S., Kim, M.-J Park, K.-K. (2016). Antilipidemic effects and gene expression profiling of the glycosaminoglycans from cricket in rats on a high fat diet. Arch Pharm Res, 39(7), 926-936. doi:10.1007/s12272-016-0749-1

Ahn, M. Y., Kim, B. J., Kim, H. J., Jin, J. M., Yoon, H. J., Hwang, J. S., Lee, B. M. (2020). Antidiabetic activity of field cricket glycosaminoglycan by ameliorating oxidative stress. BMC Complement Med Ther 20, 232 (2020). doi.org/10.1186/s12906-020-03027-x

Aiking, H., de Boer, J. (2020). The next protein transition. Trend Food Sci Technol, 105, 515-522. doi:10.1016/j.tifs.2018.07.008

Benelhadj, S., Gharsallaoui, A., Degraeve, P., Attia, H Ghorbel, D. (2016). Effect of pH on the functional properties of Arthrospira (Spirulina) platensis protein isolate. Food Chem, 194, 10561063. doi.org/10.1016/j.foodchem.2015.08.133.

Bessa, L. W., Pieterse, E., Sigge, G Hoffman, L. C. (2020). Insects as human food; from farm to fork. J Sci Food Agric, 100(14), 5017-5022. doi: $10.1002 /$ jsfa. 8860

Bose, U., Broadbent, J. A., Juhász, A., Karnaneedi, S., Johnston, E. B., Stockwell, S., ... Colgrave, M. L. (2021). Protein extraction protocols for optimal proteome measurement and arginine kinase quantitation from cricket 
Acheta domesticus for food safety assessment. Food Chem, 348, 129110.doi: 10.1016/j.foodchem.2021.129110

Boulos, S., Tännler, A Nyström, L. (2020). Nitrogen-to-Protein Conversion Factors for Edible Insects on the Swiss Market: T. molitor, $A$. domesticus, and L. migratoria. Front Nutr, 7(89). doi:10.3389/fnut.2020.00089

Cadinu, L. A., Barra, P., Torre, F., Delogu, F Madau, F. A. (2020). Insect rearing: potential, challenges, and circularity. Sustainabil, 12(11), 4567. doi:10.3390/su12114567

Caselato-Sousa, V. M., Amaya-Farfán, J. (2012). State of knowledge on Amaranth grain: A comprehensive review. J Food Sci, 77(4), R93R104. doi.org/10.1111/j.1750-

3841.2012.02645.x.

Castro, M., Chambers IV, E. (2019). Willingness to eat an insect based product and impact on brand equity: A global perspective. J Sens Stud, 34(2), e12486. doi:10.1111/joss.12486

Chalamaiah, M., Dinesh kumar, B., Hemalatha, R., Jyothirmayi, T. (2012). Fish protein hydrolysates: Proximate composition, amino acid composition, antioxidant activities and applications: A review. Food Chem, 135(4), 30203038. doi:10.1016/j.foodchem.2012.06.100

Da Rocha, M., Alemán, A., Baccan, G. C., LópezCaballero, M. E., Gómez-Guillén, C., Montero, P Prentice, C. (2018). Anti-inflammatory, antioxidant, and antimicrobial effects of underutilized fish protein hydrolysate. $J$ Aquatic Food Prod Technol, 27(5), 592-608. doi:10.1080/10498850.2018.1461160

de Carvalho, N. M., Teixeira, F., Silva, S., Madureira, A. R., Pintado, M. E. (2019). Potential prebiotic activity of Tenebrio molitor insect flour using an optimized in vitro gut microbiota model. Food Funct, 10(7), 3909-3922. doi:10.1039/C8FO01536H

de Castro, R. J. S., Ohara, A., Aguilar, J. G. d. S., Domingues, M. A. F. (2018). Nutritional, functional and biological properties of insect proteins: Processes for obtaining, consumption and future challenges. Trend Food Sci Technol, 76, 82-89. doi:10.1016/j.tifs.2018.04.006

Di Mattia, C., Battista, N., Sacchetti, G., Serafini, M. (2019). Antioxidant activities in vitro of water and liposoluble extracts obtained by different species of edible insects and invertebrates. Front Nutr, 6(106). doi:10.3389/fnut.2019.00106

EFSA Panel on Nutrition, N. F., Allergens, F., Turck, D., Castenmiller, J., De Henauw, S., Hirsch-Ernst, K. I., . . Naska, A. (2021). Safety of dried yellow mealworm (Tenebrio molitor larva) as a novel food pursuant to Regulation (EU) 2015/2283. ， 19(1), e06343. doi:10.2903/j.efsa.2021.6343

Fasolin, L. H., Pereira, R. N., Pinheiro, A. C., Martins, J. T., Andrade, C., Ramos, O Vicente, A. (2019). Emergent food proteins-Towards sustainability, health and innovation. Food Res Int, 125, 108586. doi:10.1016/j.foodres.2019.108586.

Govorushko, S. (2019). Global status of insects as food and feed source: A review. Trend Food Sci Technol, 91, 436-445. doi:10.1016/j.tifs.2019.07.032

Hall, F., Liceaga, A. (2020). Effect of microwaveassisted enzymatic hydrolysis of cricket (Gryllodes sigillatus) protein on ACE and DPP-IV inhibition and tropomyosin-IgG binding. J Funct Foods, 64, 103634. doi:10.1016/j.jff.2019.103634

Han, S.-R., Lee, B.-S., Jung, K.-J., Yu, H.-J., Yun, E.-Y., Hwang, J. S Moon, K.-S. (2016). Safety assessment of freeze-dried powdered Tenebrio molitor larvae (yellow mealworm) as novel food source: Evaluation of 90-day toxicity in SpragueDawley rats. Regul Toxicol Pharmacol, 77, 206-212. doi:10.1016/j.yrtph.2016.03.006

Hartmann, C., Shi, J., Giusto, A Siegrist, M. (2015). The psychology of eating insects: A crosscultural comparison between Germany and China. Food Qual Prefer, 44, 148-156. doi:10.1016/j.foodqual.2015.04.013

Higa, J. E., Ruby, M. B., Rozin, P. (2020). Americans' acceptance of black soldier fly larvae as food for themselves, their dogs, and farmed animals. Food Qual Prefer, 104119. doi:10.1016/j.foodqual.2020.104119 
Hosseini, S. M., Khosravi-Darani, K. (2011). Response surface methodology for mycoprotein production by Fusarium venenatum ATCC 20334.J Bioproces Biotech, 01(01), doi.org/10.4172/21559821.1000102.

Imathiu, S. (2020). Benefits and food safety concerns associated with consumption of edible insects. NFS , 18, 1-11. doi:10.1016/j.nfs.2019.11.002

Jantzen da Silva Lucas, A., Menegon de Oliveira, L., da Rocha, M., Prentice, C. (2020). Edible insects: An alternative of nutritional, functional and bioactive compounds. Food Chem, 311, 126022. doi:10.1016/j.foodchem.2019.126022

Jonas-Levi, A., Martinez, J.-J. I. (2017). The high level of protein content reported in insects for food and feed is overestimated. J Food Compos Anal, 62, 184-188. doi:10.1016/j.jfca.2017.06.004

Jung, E. Y., Lee, H.-S., Lee, H. J., Kim, J.-M., Lee, K.-W Suh, H. J. (2010). Feeding silk protein hydrolysates to $\mathrm{C} 57 \mathrm{BL} / \mathrm{KsJ}-\mathrm{db} / \mathrm{db}$ mice improves blood glucose and lipid profiles. Nutr Res, 30(11), 783-790. doi:10.1016/j.nutres.2010.10.006

Kamal, M. M., Ali, M. R., Shishir, M. R. I., Saifullah, M., Haque, M. R Mondal, S. C. (2019). Optimization of process parameters for improved production of biomass protein from Aspergillus niger using banana peel as a substrate. Food Sci Biotechnol, 7;28(6):1693-1702. doi.org/10.1007/s10068-019-00636-2.

Kinyuru, J. N., Konyole, S. O., Roos, N., Onyango, C. A., Owino, V. O., Owuor, B. O., . . . Kenji, G. M. (2013). Nutrient composition of four species of winged termites consumed in western Kenya. J Food Compos Anal, 30(2), 120124. doi:10.1016/j.jfca.2013.02.008

Kornher, L., Schellhorn, M Vetter, S. (2019). Disgusting or innovative-consumer willingness to pay for insect based burger patties in germany. Sustainabil, 11(7), 1878. doi:10.3390/su11071878

Laurens, L. M. L., Markham, J., Templeton, D. W., Christensen, E. D., Van Wychen, S., Vadelius, E. W., ... Pienkos, P. T. (2017). Development of algae biorefinery concepts for biofuels and bioproducts; a perspective on process-compatible products and their impact on cost-reduction. Energy Environ Sci, 10(8), 1716-1738. doi.org/10.1039/C7EE01306J.

Liu, Y., Yu, L., Guo, X., Guo, T., Wang, S., Lu, C. (2006). Analysis of tissue-specific region in sericin 1 gene promoter of Bombyx mori. Biochem Biophys Res Commun, 342(1), 273-279. doi:10.1016/j.bbrc.2006.01.140

Murefu, T. R., Macheka, L., Musundire, R., Manditsera, F. A. (2019). Safety of wild harvested and reared edible insects: A review. Food Control, 101 , 209-224. doi:10.1016/j.foodcont.2019.03.003

Najafian, L., Babji, A. S. (2012). A review of fishderived antioxidant and antimicrobial peptides: Their production, assessment, and applications. Peptides, 33(1), 178-185. doi:10.1016/j.peptides.2011.11.013

Nissen, L., Samaei, S. P., Babini, E., Gianotti, A. (2020). Gluten free sourdough bread enriched with cricket flour for protein fortification: Antioxidant improvement and volatilome characterization. Food Chem, 333, 127410. doi:10.1016/j.foodchem.2020.127410

Nongonierma, A. B., FitzGerald, R. J. (2017). Unlocking the biological potential of proteins from edible insects through enzymatic hydrolysis: A review. IFSET, 43, 239-252. doi:10.1016/j.ifset.2017.08.014

Nowakowski, A. C., Miller, A. C., Miller, M. E., Xiao, H., Wu, X. (2021). Potential health benefits of edible insects. Crit Rev Food Sci Nutr, 1-10. doi:10.1080/10408398.2020.1867053

Oonincx, D. G. A. B., Dierenfeld, E. S. (2012). An investigation into the chemical composition of alternative invertebrate prey. Zoo Biol, 31(1), 4054. doi: $10.1002 /$ zoo.20382

Ordoñez-Araque, R., Egas-Montenegro, E. (2021). Edible insects: A food alternative for the sustainable development of the planet. Int J Gastron Food Sci, 23, 100304. doi:10.1016/j.ijgfs.2021.100304

Poma, G., Cuykx, M., Amato, E., Calaprice, C., Focant, J. F., Covaci, A. (2017). Evaluation of 
hazardous chemicals in edible insects and insectbased food intended for human consumption. Food Chem Toxicol, 100, 70-79. doi:10.1016/j.fct.2016.12.006

Piha, S., Pohjanheimo, T., Lähteenmäki-Uutela, A., Křečková, Z., Otterbring, T. (2018). The effects of consumer knowledge on the willingness to buy insect food: An exploratory cross-regional study in Northern and Central Europe. Food Qual Prefer, $\quad 70, \quad 1-10$. doi:10.1016/j.foodqual.2016.12.006

Rahnamaeian, M., Cytryńska, M., ZdybickaBarabas, A., Dobslaff, K., Wiesner, J., Twyman, R. M., . . . Vilcinskas, A. (2015). Insect antimicrobial peptides show potentiating functional interactions against gram-negative bacteria. Proc Biol Sci, 282(1806), 20150293. doi:10.1098/rspb.2015.0293

Ravi, H. K., Degrou, A., Costil, J., Trespeuch, C., Chemat, F., Vian, M. A. (2020). Larvae mediated valorization of industrial, agriculture and food wastes: biorefinery concept through bioconversion, processes, procedures, and products. Process, $8(7), \quad 857$. doi:10.3390/pr8070857

Ribeiro, J. C., Cunha, L. M., Sousa-Pinto, B., Fonseca, J. (2018). Allergic risks of consuming edible insects: A systematic review. Mol Nutr Food Res, 62(1), 1700030. doi:10.1002/mnfr.201700030

Ribeiro, J. C., Sousa-Pinto, B., Fonseca, J., Fonseca, S. C., Cunha, L. M. (2021). Edible insects and food safety: allergy. J Insects Food Feed, 1-16. doi: 10.3920/JIFF2020.0065

Ruby, M. B., Rozin, P., Chan, C. (2015). Determinants of willingness to eat insects in the USA and India. J Insects Food Feed, 1(3), 215-225. doi: 10.3920/JIFF2015.0029

Ruby, M. B., Rozin, P. (2019). Disgust, sushi consumption, and other predictors of acceptance of insects as food by Americans and Indians. Food Qual Prefer, 74, 155-162. doi:10.1016/j.foodqual.2019.01.013

Ruiz, G. A., Xiao, W., van Boekel, M., Minor, M., Stieger, M. (2016). Effect of extraction pH on heat-induced aggregation, gelation and microstructure of protein isolate from quinoa (Chenopodium quinoa Willd). Food Chem, 209, 203210. doi.org/10.1016/j.foodchem.2016.04.052

Rumpold, B. A., Schlüter, O. K. (2013). Nutritional composition and safety aspects of edible insects. Mol Nutr Food Res, 57(5), 802-823. doi:10.1002/mnfr.201200735

Sarmadi, B. H., Ismail, A. (2010). Antioxidative peptides from food proteins: A review. Peptides, 31(10), 1949-1956. doi:10.1016/j.peptides.2010.06.020

Stone, A. K., Tanaka, T Nickerson, M. T. (2019). Protein quality and physicochemical properties of commercial cricket and mealworm powders. $J$ Food Sci Technol, 56(7), 3355-3363. doi:10.1007/s13197-019-03818-2

Stull, V. J., Finer, E., Bergmans, R. S., Febvre, H. P., Longhurst, C., Manter, D. K., . . . Weir, T. L. (2018). Impact of edible cricket consumption on gut microbiota in healthy adults, a double-blind, randomized crossover trial. Sci Rep, 8(1), 10762. doi:10.1038/s41598-018-29032-2

Sun-Waterhouse, D., Waterhouse, G. I. N., You, L., Zhang, J., Liu, Y., Ma, L., ... Dong, Y. (2016). Transforming insect biomass into consumer wellness foods: A review. Food Res Int, 89, 129151. doi:10.1016/j.foodres.2016.10.001

Tao, J., Li, Y. O. (2018). Edible insects as a means to address global malnutrition and food insecurity issues. FQS, 2(1), 17-26. doi:10.1093/fqsafe/fyy001

Tuccillo, F., Marino, M. G., Torri, L. (2020). Italian consumers' attitudes towards entomophagy: Influence of human factors and properties of insects and insect-based food. Food Res Int, 137, 109619. doi:10.1016/j.foodres.2020.109619

Ursu, A.-V., Marcati, A., Sayd, T., SanteLhoutellier, V., Djelveh, G., Michaud, P. (2014). Extraction, fractionation and functional properties of proteins from the microalgae Chlorella vulgaris. Bioresour Technol, 157, 134-139. doi.org/10.1016/j.biortech.2014.01.071.

UN, Department of Economic and Social Affairs, Population Division. (2017). World population 
prospects: The 2017 revision, key findings and advance tables. (ESA/P/WP/248).

van Huis, A., Van Itterbeeck, J., Klunder, H., Mertens, E., Halloran, A., Muir, G., Vantomme, P. (2013). Edible insects: future prospects for food and feed security (No. 171). FAO.

Van der Fels-Klerx, H. J., Camenzuli, L., Belluco, S., Meijer, N., Ricci, A. (2018). Food safety issues related to uses of insects for feeds and foods. Compr Rev Food Sci Food Saf, 17(5), 1172-1183. doi:10.1111/1541-4337.12385

Vercruysse, L., Smagghe, G., Herregods, G., Van Camp, J. (2005). ACE inhibitory activity in enzymatic hydrolysates of insect protein. J Agric Food Chem, 53(13), 5207-5211. doi:10.1021/jf050337q

Wade, M., Hoelle, J. (2020). A review of edible insect industrialization: scales of production and implications for sustainability. Environ Res Lett, 15(12), 123013. doi:10.1088/1748-9326/aba1c1

Woolf, E., Zhu, Y., Emory, K., Zhao, J., Liu, C. (2019). Willingness to consume insect-containing foods: A survey in the United States. $L W T, 102$, 100-105. doi:10.1016/j.lwt.2018.12.010

Yi, L., Lakemond, C. M. M., Sagis, L. M. C., Eisner-Schadler, V., van Huis, A., van Boekel, M.
A. J. S. (2013). Extraction and characterisation of protein fractions from five insect species. Food Chem, 141(4), 3341-3348. doi:10.1016/ j.foodchem.2013.05.115

Yüksel, E., Canhilal, R. (2018). A survey of public opinion about entomophagy in Erciyes University. IJ $A W S, \quad 4(2), \quad 203 \quad-208$. doi:10.24180/ijaws.440555

Zielińska, E., Baraniak, B., Karaś, M., Rybczyńska, K., Jakubczyk, A. (2015). Selected species of edible insects as a source of nutrient composition. Food Res Int, 77, 460-466. doi:10.1016/j.foodres.2015.09.008

Zielińska, E., Baraniak, B., Karaś, M. (2017). Antioxidant and anti-inflammatory activities of hydrolysates and peptide fractions obtained by enzymatic hydrolysis of selected heat-treated edible insects. Nutrients, 9(9), 970. doi:10.3390/nu9090970

Zielińska, E., Pankiewicz, U. (2020). Nutritional, physiochemical, and antioxidative characteristics of shortcake biscuits enriched with tenebrio molitor flour. Molecules, 25(23), 5629. doi:10.3390/molecules25235629 